\title{
Pharmacists' Research Contributions in the Fight against HIV/AIDs
}

\author{
Alexis E. Horace \\ College of Pharmacy, University of Louisiana at Monroe, Baton Rouge Campus, 3849 North Boulevard, Baton Rouge, \\ LA 70808, USA \\ Correspondence should be addressed to Alexis E. Horace, horace@ulm.edu
}

Received 16 January 2012; Accepted 7 August 2012

Academic Editor: Giuseppe Ippolito

Copyright ( 2012 Alexis E. Horace. This is an open access article distributed under the Creative Commons Attribution License, which permits unrestricted use, distribution, and reproduction in any medium, provided the original work is properly cited.

Pharmacists have made many contributions to HIV/AIDs research and are still showing their significance as members of the healthcare team through innovative clinical trials. Pharmacists are showing advances in several healthcare settings including inpatient, outpatient, and community pharmacies. Because of the complex regimens of highly active antiretroviral therapy (HAART), the increased life span of patients living with HIV, and other concomitant medications taken for comorbid disease states, there is a high risk for health-related complications and the development of adverse events. These adverse events may lead to decreased adherence to HAART, which may cause the development of HIV drug resistance. Pharmacists are providing examples through growing research on how they help combat medication-related errors and also continue to contribute as healthcare providers as a part of a holistic healthcare team.

\section{Introduction}

With the invention and administration of highly active antiretroviral therapy (HAART), human immunodeficiency virus (HIV) has transformed from an acute disease to a chronic disease. The Centers for Disease Control and Prevention estimate that between the years 1996-2003, HAART extended life expectancy of patients living with HIV from 10 to 20 years [1]. Care for patients infected with HIV has shifted from primarily requiring acute treatment in the inpatient setting to needing chronic treatment in the primary and ambulatory care settings. During this time, pharmacists have assumed larger roles as members of healthcare teams who specialize in caring for patients of this population. The responsibilities of pharmacists surpass caring for HIV patients in a community pharmacy setting and have evolved into participating in direct patient care in hospitals and outpatient clinics.

Concerns for patients with HIV extend beyond increasing CD4 cell counts and decreasing viral loads. Successful treatment for patients with this disease state depends on a holistic, patient-specific approach by a multidisciplinary team [9]. Management of all aspects of HAART is needed for successful treatment. Clinical pharmacists can provide many services such as pharmacokinetic drug monitoring, medication reconciliation, therapeutic medication recommendations, patient counseling, adherence consult services, and medication therapy management. These services have prevented medication errors, decreased medication misuse, and increased health-related outcomes [10-12]. Due to the complexity of HAART, there is a greater need to monitor adverse effects, drug-drug interactions, and resistance patterns of HIV-1 virus that can develop through patient nonadherence.

Patients may require treatment for chronic disease states such as hepatitis coinfection, or, solid organ transplant, diabetes, cardiovascular disease, or renal disease, which also use many medications for treatment further increasing the chance for drug interactions to occur.

Pharmacists have demonstrated their usefulness in the clinical setting through providing cost savings by making valuable therapeutic interventions [13-15]. Kopp and colleagues showed pharmacists' interventions over 4.5 months of service provided a cost avoidance of $\$ 205,919-\$ 280,421$ 
[16]. Not only do pharmacists play a vital role as a part of the healthcare team providing optimal care for patients with HIV, but also they are a cost-effective resource.

The role of pharmacists treating patients with HIV is constantly evolving. The American Society of Health System Pharmacists (ASHP) released a statement in 2003 that supports the use of clinical pharmacists in caring for patients with this disease state [17]. ASHP suggests that possible areas for implementation of pharmacists include outpatient pharmacies, ambulatory care clinics, inpatient settings, dialysis units, hospice care centers, and home health services. Since the publication of this statement, there has been a plethora of studies documenting the contributions of pharmacists in the fight against HIV. This paper reviews efforts of pharmacists and pharmacy services to aid in the management of this disease state and provides insight into areas for expanding future research.

\section{Hospital Pharmacy}

Patients with chronic disease states are at risk for medicationrelated errors upon admission to the hospital [18]. Drug interactions with HAART can significantly increase or decrease therapeutic levels of medications [19] putting patients at risk for adverse effects or the development of HIV-1 viral resistance. An adherence rate of $95 \%$ to antiretroviral (ARV) therapy is recommended in order to sustain acceptable CD4 counts and viral load levels [20]. The medication-related errors that occur during inpatient hospital stays are more detrimental than they may appear on the surface [20]. Early retrospective studies documenting the need for pharmacy intervention report clinically significant error rates in prescribing ARVs of 5.8\% over a 2 -year period and $26 \%$ over a 1 -year period $[21,22]$. Because of the impact these errors can make on the health of HIV positive patients, research has emerged showing how the participation of pharmacists decreases these risks.

In 2007, Heelon and colleagues [23] published data describing the $\mathrm{AV}$ prescribing errors in an inpatient hospital setting and the effects of a clinical pharmacist in decreasing these errors. This descriptive, observational study was constructed in two parts consisting of a preintervention phase and an intervention phase. They found that $21 \%$ of HIV patients had at least one HAART prescribing error during their hospital stay. Most errors consisted of incomplete regimens $(45 \%)$, incorrect dosage forms $(30 \%)$, and incorrect scheduling (8\%). With the help of a pharmacist, the duration of errors also decreased from 3.5 days to 1 day until resolution.

That same year, another study examined the effect of clinical pharmacy on health outcomes for HIV patients [12]. This observational study reviewed 1571 patients in clinics with or without a clinical pharmacist's involvement. Patients with access to a clinical pharmacist (47\%) were associated with decreases in plasma HIV-1 virus levels of $0.73 \mathrm{log}$ $(P<0.001)$ within 1 year and $0.33 \log (P=0.005)$ within 2 years. There were no statistically significant changes in CD4 T-cell counts after 2 years. Outcomes varied depending on the size of the practice site. For instance, the clinical pharmacist group associated with patient population of $<50$ were associated with a $19 \%$ (95\% CI: $-40 \%$ to $8 \%)$ decrease in office visits; however, for sites with panel sizes $>50 \mathrm{HIV}$ patients, there was a $10 \%$ increase ( $95 \%$ CI: $-16 \%$ to $43 \%$ ). Patients who had access to a clinical pharmacist required fewer clinic visits $(0.88$ fewer, $P<0.001)$. In addition, adherence rates in patients in the clinical pharmacists group improved to $7.1 \%$ at 1 year ( $81 \%$ versus $74 \%, P=0.04$ ) and $7.8 \%$ at 2 years $(76.7 \%$ versus $68.9 \%, P=0.02)$.

In the years that followed, other research on the impact of clinical pharmacists in the hospital setting emerged. A small study published by Mok and colleagues supports previous data reporting high rates of incomplete regimens for HIV patients admitted to the hospital (36\% of patients, $n=83$ ) and $86 \%$ of patients had at least one medication error involving HAART [24]. Also, a 3-month descriptive, prospective study conveyed similar results reporting rates of incomplete regimens in hospitalized patients as high as $42 \%(n=50)$ and, with the aid of clinical pharmacists' recommendations, all patients admitted were started on appropriate regimens $(n=34)$ [25]. Another study reflected similar data [26]. However, the authors rated the risk level of each error. In a population of 68 HIV patients hospitalized over a 4-month period, $56 \%$ had at least one error that caused moderate-to-severe discomfort. Another interesting aspect of this study was the authors ability to associate an approximately 2-fold increase in the risk of experiencing HIV medication errors with the hospital pharmacy's inability to provide correct substitutions for nonformulary medications $(\mathrm{RR}=1.95 ; 95 \%$ CI 1.25 to $3.4 ; P=0.02)$. Not only did this study provide insight on the severity of errors detected and the importance of a pharmacist's intervention on these errors, but also it provided information on improvements the department of pharmacy could implement when dispensing AVs.

A larger study emerged in 2011 by Carcelero and colleagues identifying common prescribing errors involving AVs, and also, evaluating the level of acceptance of pharmacy-provided recommendations [27]. This observational, prospective study was conducted over 1 year and included 189 HIV-infected patients. Similar rates of medication-related errors were found in comparison to previous studies (21.7\% of patients had at least one error). The pharmacist made an intervention for all detected errors with $91.7 \%$ of recommendations being accepted. The data presented supports the need for the incorporation of clinical pharmacist in the care for patients hospitalized with HIV/AIDS. Services provided by clinical pharmacists should be taken into consideration in this practicing setting.

\section{Outpatient Clinics and Community Pharmacies}

Care for patients with HIV/AIDs extends beyond the inpatient setting to outpatient settings as rates for developing opportunistic infections continue to decrease [28]. There are 
TABLE 1: Pharmacist impact on adherence in patients with HIV/AIDs.

\begin{tabular}{|c|c|c|c|c|c|c|}
\hline Authors & Year & Analysis type & Objective & $\begin{array}{c}\text { No. of } \\
\text { patients }\end{array}$ & Results & $\begin{array}{l}\text { Statistical } \\
\text { value }\end{array}$ \\
\hline \multirow{2}{*}{$\begin{array}{l}\text { Cantwell- } \\
\text { McNelis } \\
\text { and James } \\
{[2]}\end{array}$} & \multirow[t]{2}{*}{2002} & \multirow[t]{2}{*}{ Retrospective } & \multirow{2}{*}{$\begin{array}{l}\text { Evaluation of a } \\
\text { pharmacist run } \\
\text { adherence program }\end{array}$} & \multirow[t]{2}{*}{80} & $\begin{array}{l}\text { (i) Increase in refill rates by patients in } \\
\text { contact with a pharmacist ( } 31 \text { versus } \\
50 \text { days) }\end{array}$ & $P<0.05$ \\
\hline & & & & & $\begin{array}{l}\text { (ii) Significant decrease in viral load } \\
\text { (values not reported) }\end{array}$ & $P<0.05$ \\
\hline $\begin{array}{l}\text { Foisy and } \\
\text { Akai }[3]\end{array}$ & 2004 & $\begin{array}{l}\text { Observational, } \\
\text { prospective }\end{array}$ & $\begin{array}{l}\text { Describe the } \\
\text { implementation of a } \\
\text { pharmacy driven } \\
\text { direct-observation } \\
\text { therapy service }\end{array}$ & 57 & $\begin{array}{l}\text { (i) } 149 \text { drug-related problems identified } \\
\text { with } 95 \% \text { acceptance of } \\
\text { recommendations } \\
\text { (ii) } 13.4 \% \text { drug-related problems } \\
\text { included adherence }\end{array}$ & \\
\hline \multirow{2}{*}{$\begin{array}{l}\text { Castillo } \\
\text { et al. [4] }\end{array}$} & \multirow[b]{2}{*}{2004} & \multirow[b]{2}{*}{$\begin{array}{l}\text { Retrospective, } \\
\text { observational }\end{array}$} & \multirow{2}{*}{$\begin{array}{l}\text { Compare the impact of } \\
\text { different levels of } \\
\text { pharmacy care on } \\
\text { adherence and time to } \\
\text { viral suppression }\end{array}$} & \multirow[b]{2}{*}{489} & $\begin{array}{l}\text { (i) AIDS-tertiary pharmacies had highest } \\
\text { rates of adherence compared to } \\
\text { outside pharmacies and physician } \\
\text { clinics }\end{array}$ & $P=0.000$ \\
\hline & & & & & $\begin{array}{l}\text { (ii) Probability of HIV-1 RNA suppression } \\
\text { by } 12 \text { months was } 74.6 \% \text { for the AIDS } \\
\text { tertiary pharmacies, } 59.4 \% \text { for off site } \\
\text { pharmacies, and } 60 \% \text { for physician } \\
\text { offices }\end{array}$ & $P=0.001$ \\
\hline \multirow{2}{*}{$\begin{array}{l}\text { Hirsch } \\
\text { et al. [5] }\end{array}$} & \multirow[b]{2}{*}{2009} & \multirow[b]{2}{*}{ Cohort } & \multirow{2}{*}{$\begin{array}{l}\text { Investigate the impact of } \\
\text { pharmacy established } \\
\text { MTM services }\end{array}$} & \multirow[b]{2}{*}{7,018} & $\begin{array}{l}\text { (i) } 56.3 \% \text { adherence in pilot pharmacy } \\
\text { compared to } 38.1 \% \text { in comparison } \\
\text { group }\end{array}$ & $P<0.001$ \\
\hline & & & & & $\begin{array}{l}\text { (ii) Difference in excess refills }(19.7 \% \\
\text { versus } 44.8 \% \text {, pilot pharmacy versus } \\
\text { other pharmacies) }\end{array}$ & $P<0.001$ \\
\hline \multirow{3}{*}{$\begin{array}{l}\text { Ma et al. } \\
{[6]}\end{array}$} & \multirow{3}{*}{2010} & \multirow{3}{*}{ Retrospective, cohort } & \multirow{3}{*}{$\begin{array}{l}\text { Investigate clinical } \\
\text { outcomes of an HIV } \\
\text { clinical pharmacist } \\
\text { interventions }\end{array}$} & \multirow{3}{*}{75} & $\begin{array}{l}\text { (i) Prescribed daily pill quantities } \\
\text { reduced from a mean of } 7.2 \pm 3.9 \text { to } \\
5.4 \pm 2.8 \text { pills per day }\end{array}$ & $P<0.001$ \\
\hline & & & & & (ii) $25 \%$ increase in CD $4+$ cell count & $P<0.001$ \\
\hline & & & & & $\begin{array}{l}\text { (iii) } 33 \% \text { increase in patients with } \\
\text { undetectable viral load }\end{array}$ & $P<0.0001$ \\
\hline \multirow{2}{*}{$\begin{array}{l}\text { Henderson } \\
\text { et al. [7] }\end{array}$} & \multirow{2}{*}{2011} & \multirow{2}{*}{ Prospective, cohort } & \multirow{2}{*}{$\begin{array}{l}\text { Evaluating antiretroviral } \\
\text { adherence and impact of } \\
\text { pharmacy interventions }\end{array}$} & \multirow{2}{*}{28} & $\begin{array}{l}\text { (i) Overall 19\% increase in adherence } \\
\text { rates }\end{array}$ & $P<0.00001$ \\
\hline & & & & & $\begin{array}{l}\text { (ii) Increase in the trend toward } \\
\text { undetectable viral load (58-73\%, } \\
\text { baseline and postintervention) }\end{array}$ & $P=1.0$ \\
\hline $\begin{array}{l}\text { Hirsch } \\
\text { et al. [8] }\end{array}$ & 2011 & Cohort & $\begin{array}{l}\text { Evaluation of pharmacy } \\
\text { driven MTM services }\end{array}$ & 2,234 & $\begin{array}{l}\text { Increased adherence in the pilot pharmacy } \\
\text { than nonpilot pharmacy by } 22.1 \%\end{array}$ & $P<0.001$ \\
\hline
\end{tabular}

MTM: medication therapy management, AIDS: acquired immunodeficiency syndrome, HIV: human immunodeficiency virus.

now opportunities for pharmacists to participate in the continuity of care for these patients as they transition from one area of healthcare to another. One study reports discrepancy rates as high as $53 \%$ when comparing community pharmacy and outpatient clinic medication records for patients on $\mathrm{AVs}$ [29]. In addition to the monitoring patient tolerance of these complex ARV regimens and identifying drug-drug interactions between ARVs and medications taken for other chronic disease states, pharmacists also have opportunities to assist in adherence counseling and help to optimize drug therapy. Taking AVs is a long-term commitment and requires excellent adherence. The level of patient adherence is crucial in optimizing therapeutic outcomes [20]. Length of therapy, psychological comorbidities, larger pill burden, increased frequency of administration, and baseline viral loads with associated resistance patterns are determinants of adherence [30]. In a retrospective study $(n=80)$ that reviews adherence by use of refill data, more patients receiving counseling from a pharmacist refilled their prescriptions in a timely manner than those who did not $(P<0.05)[31]$.

March and colleagues published a study in 2007 that showed data on the effects of pharmacists' interventions on patient outcomes in an HIV clinic [32]. Patients recruited to this study had an extensive history with AV therapy. In this observational trial which lasted approximately 4 months, $68 \%$ of the patients ( 23 out of 34 ) had more than one medication problem that required therapeutic recommendations from the pharmacist. During this time, the clinic's primary care providers accepted $100 \%$ of recommendations. When observing CD4+ cells, they found counts increased 
from baseline levels by $54 \pm$ cells $/ \mathrm{mm}^{3}(P<0.0002)$ over the course of the study. The mean reduction in viral load was $1.02 \log _{10}$ copies $/ \mathrm{mL}(P<0.004)$. Though this study is small, it shows that the help of a clinical pharmacist has some benefits. This study also highlights an area for further research for pharmacists hoping to make further impacts on the fight against HIV.

There are several other studies published that provide additional support to the use of pharmacy when caring for patients with HIV (Table 1). Not only are clinical pharmacists vital in the clinical setting, but also the use of specialty pharmacies for HIV patients or pharmacistrun medication therapy management (MTM) clinics have made a great impact. Opportunities for improvement lie in continuing to document pharmacy-related services to show health outcomes and cost savings in relation to pharmacists' interventions. Hopefully the continuation of research in this area will further establish clinical settings where pharmacists are needed.

\section{Conclusion}

Currently there are many effective medications used to treat HIV, however these medications may result in significant harm (increased toxicity) or viral resistance when they are not prescribed, administered, or taken correctly [20, 33, 34]. Pharmacists are taking a larger responsibility in caring for patients with HIV, and studies revealing our efforts are increasing. Nonetheless, many of these efforts go undocumented. There are clinical trials published supporting the use of pharmacists in both inpatient and outpatient clinical settings; however, knowledge of the usefulness of these services is often overlooked. Pharmacists are knowledgeable about medications and their management, providing a unique advantage when caring for patients with this disease state. Most studies published showing the effectiveness of pharmacists in treating patients with HIV are limited by their small study size and short duration. Some studies reported outcomes for patients with improvements in CD4+ cells and viral suppression, which can be attributed to the influence of pharmacist recommendations and collaborative efforts. These studies should spur efforts to increase research in using pharmacists as accessible and valuable resources for helping to manage patients with HIV. Another possible area of research could include using pharmacists as resources to enhance continuity of care from the hospital setting to the outpatient clinic setting, acting as guides to provide complete medication reconciliation and possibly decrease drug-related errors. There is also a lack of data researching pharmacy services in areas such as hospice and dialysis centers. These areas are also new realms for research regarding the influence of pharmacists in practice. Pharmacy as a profession is continuously evolving and pharmacists are increasingly seeking opportunities to become more involved in direct patient care. Though there are still many opportunities for research into pharmacists' involvement in care of patients with HIV, pharmacists are currently making vast improvements in the level of patient-centered care they provide for patients living with this complex disease state.

\section{References}

[1] Center for Disease Control and Prevention (CDC), Decline in AIDS Deaths Indicate Continued Success of New HIV Treatments, and Suggests Continued Increase in HIV Prevalence. CDC Update: National Center For HIV, STD \& TB Prevention, Centers for disease control and Prevention, Atlanta, Ga, USA, 1998.

[2] K. Cantwell-McNelis and C. W. James, "Role of clinical pharmacists in outpatient HIV clinics," American Journal of Health-System Pharmacy, vol. 59, no. 5, pp. 447-452, 2002.

[3] M. M. Foisy and P. S. Akai, "Pharmaceutical care for HIV patients on directly observed therapy," Annals of Pharmacotherapy, vol. 38, no. 4, pp. 550-556, 2004.

[4] E. Castillo, A. Palepu, A. Beardsell et al., "Outpatient pharmacy care and HIV viral load response among patients on HAART," AIDS Care, vol. 16, no. 4, pp. 446-457, 2004.

[5] J. D. Hirsch, A. Rosenquist, B. M. Best, T. A. Miller, and T. P. Gilmer, "Evaluation of the first year of a pilot program in community pharmacy: HIV/AIDS medication therapy management for Medi-Cal beneficiaries," Journal of Managed Care Pharmacy, vol. 15, no. 1, pp. 32-41, 2009.

[6] A. Ma, D. M. Chen, F. M. Chau, and P. Saberi, "Improving adherence and clinical outcomes through an HIV pharmacist's interventions," AIDS Care, vol. 22, no. 10, pp. 1189-1194, 2010.

[7] K. C. Henderson, J. Hindman, S. C. Johnson, R. J. Valuck, and J. J. Kiser, "Assessing the effectiveness of pharmacybased adherence interventions on antiretroviral adherence in persons with HIV," AIDS Patient Care and STDs, vol. 25, no. 4, pp. 221-228, 2011.

[8] J. D. Hirsch, M. Gonzales, A. Rosenquist, T. A. Miller, T. P. Gilmer, and B. M. Best, "Antiretroviral therapy adherence, medication use, and health care costs during 3 years of a community pharmacy medication therapy management program for Medi-Cal beneficiaries with HIV/AIDS," Journal of Managed Care Pharmacy, vol. 17, no. 3, pp. 213-223, 2011.

[9] R. W. Levy, C. R. Rayner, C. K. Fairley et al., "Multidisciplinary HIV adherence intervention: a randomized study," AIDS Patient Care and STDs, vol. 18, no. 12, pp. 728-735, 2004.

[10] J. T. Hanlon, M. Weinberger, G. P. Samsa et al., "A randomized, controlled trial of a clinical pharmacist intervention to improve inappropriate prescribing in elderly outpatients with polypharmacy," American Journal of Medicine, vol. 100, no. 4, pp. 428-437, 1996.

[11] L. L. Leape, D. J. Cullen, M. D. Clapp et al., "Pharmacist participation on physician rounds and adverse drug events in the intensive care unit," JAMA, vol. 282, no. 3, pp. 267-270, 1999.

[12] M. A. Horberg, L. B. Hurley, M. J. Silverberg, C. J. Kinsman, and C. P. Quesenberry, "Effect of clinical pharmacists on utilization of and clinical response to antiretroviral therapy," Journal of Acquired Immune Deficiency Syndromes, vol. 44, no. 5, pp. 531-539, 2007.

[13] G. T. Schumock, P. D. Meek, P. A. Ploetz, and L. C. Vermeulen, "Economic evaluations of clinical pharmacy services-19881995," Pharmacotherapy, vol. 16, no. 6, pp. 1188-1208, 1996.

[14] A. J. Lee, M. S. Boro, K. K. Knapp, J. L. Meier, and N. E. Korman, "Clinical and economic outcomes of pharmacist recommendations in a Veterans Affairs medical center," American Journal of Health-System Pharmacy, vol. 59, no. 21, pp. 20702077, 2002.

[15] T. De Rijdt, L. Willems, and S. Simoens, "Economic effects of clinical pharmacy interventions: a literature review," American 
Journal of Health-System Pharmacy, vol. 65, no. 12, pp. 11611172, 2008.

[16] B. J. Kopp, M. Mrsan, B. L. Erstad, and J. J. Duby, "Cost implications of and potential adverse events prevented by interventions of a critical care pharmacist," American Journal of Health-System Pharmacy, vol. 64, no. 23, pp. 2483-2487, 2007.

[17] "ASHP statement on the pharmacist's role in the care of patients with HIV infection," American Journal of HealthSystem Pharmacy, vol. 60, no. 19, pp. 1998-2003, 2003.

[18] P. L. Cornish, S. R. Knowles, R. Marchesano et al., "Unintended medication discrepancies at the time of hospital admission," Archives of Internal Medicine, vol. 165, no. 4, pp. 424-429, 2005.

[19] D. S. Schiller, "Identification, management, and prevention of adverse effects associated with highly active antiretroviral therapy," American Journal of Health-System Pharmacy, vol. 61, no. 23, pp. 2507-2522, 2004.

[20] D. L. Paterson, S. Swindells, J. Mohr et al., "Adherence to protease inhibitor therapy and outcomes in patients with HIV infection," Annals of Internal Medicine, vol. 133, no. 1, pp. 2130, 2000.

[21] B. D. Purdy, A. M. Raymond, and T. S. Lesar, "Antiretroviral prescribing errors in hospitalized patients," Annals of Pharmacotherapy, vol. 34, no. 7-8, pp. 833-838, 2000.

[22] D. A. Rastegar, A. M. Knight, and J. S. Monolakis, "Antiretroviral medication errors among hospitalized patients with HIV infection," Clinical Infectious Diseases, vol. 43, no. 7, pp. 933938, 2006.

[23] M. Heelon, D. Skiest, G. Tereso et al., "Effect of a clinical pharmacist's interventions on duration of antiretroviralrelated errors in hospitalized patients," American Journal of Health-System Pharmacy, vol. 64, no. 19, pp. 2064-2068, 2007.

[24] S. Mok and Q. Minson, "Drug-related problems in hospitalized patients with HIV infection," American Journal of HealthSystem Pharmacy, vol. 65, no. 1, pp. 55-59, 2008.

[25] A. Horace and M. Philips, "Identification and prevention of antiretroviral medication errors at an academic medical center," Hospital Pharmacy, vol. 45, no. 12, pp. 927-933, 2010.

[26] S. D. Pastakia, A. H. Corbett, R. H. Raasch, S. Napravnik, and T. A. Correll, "Frequency of HIV-related medication errors and associated risk factors in hospitalized patients," Annals of Pharmacotherapy, vol. 42, no. 4, pp. 491-497, 2008.

[27] E. Carcelero, M. Tuset, M. Martin et al., "Evaluation of antiretroviral-related errors and interventions by the clinical pharmacist in hospitalized HIV-infected patients," HIV Medicine, vol. 12, pp. 494-499, 2011.

[28] S. G. Deeks, M. Smith, M. Holodniy, and J. O. Kahn, "HIV1 protease inhibitors: a review for clinicians," JAMA, vol. 277, no. 2, pp. 145-153, 1997.

[29] M. M. R. De Maat, S. V. Frankfort, R. A. A. Mathôt et al., "Discrepancies between medical and pharmacy records for patients on anti-HIV drugs," Annals of Pharmacotherapy, vol. 36, no. 3, pp. 410-415, 2002.

[30] M. J. Atkinson and J. J. Petrozzino, "An evidence-based review of treatment-related determinants of patients' nonadherence to HIV medications," AIDS Patient Care and STDs, vol. 23, no. 11, pp. 903-914, 2009.

[31] K. McNelis, S. Szabo, R. Bidwell et al., "Adherence strategies in a Title III EIS program," in Ryan White Care Act All-Title National Meeting, Washington, DC, USA, January 2000.

[32] K. March, M. Mak, and S. G. Louie, "Effects of pharmacists' interventions on patient outcomes in an HIV primary care clinic," American Journal of Health-System Pharmacy, vol. 64, no. 24, pp. 2574-2578, 2007.

[33] L. G. Miller and R. D. Hays, "Adherence to combination antiretroviral therapy: synthesis of the literature and clinical implications," AIDS Reader, vol. 10, no. 3, pp. 177-185, 2000.

[34] C. E. Reust, "Common adverse effects of antiretroviral therapy for HIV disease," American Family Physician, vol. 83, no. 12, pp. 1443-1451, 2011. 


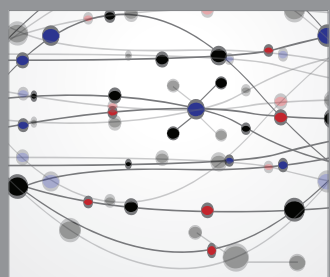

The Scientific World Journal
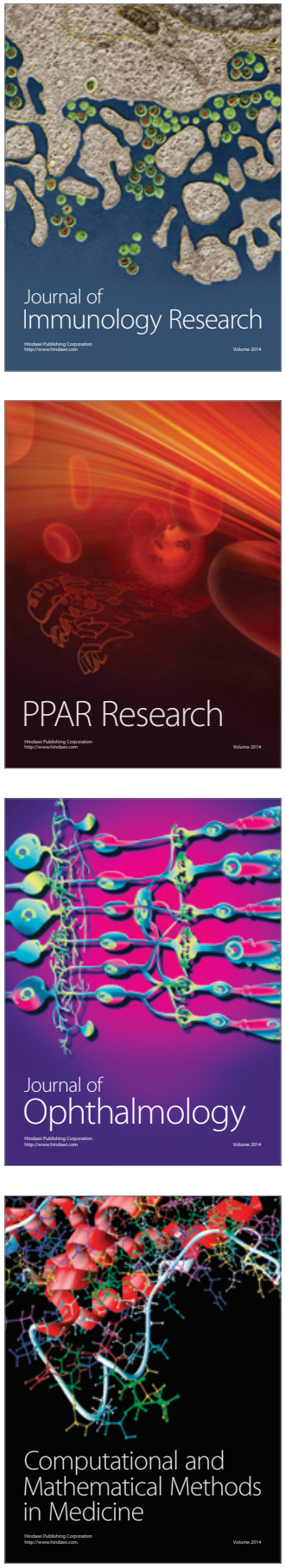

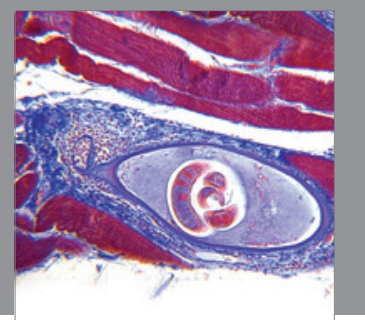

Gastroenterology

Research and Practice
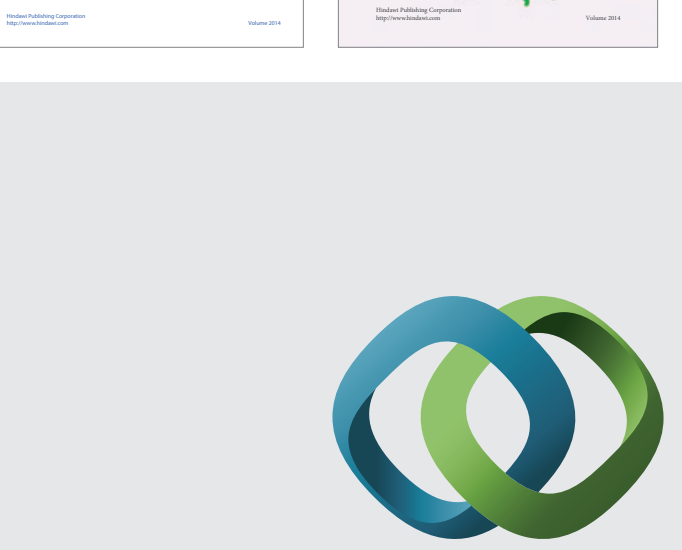

\section{Hindawi}

Submit your manuscripts at

http://www.hindawi.com
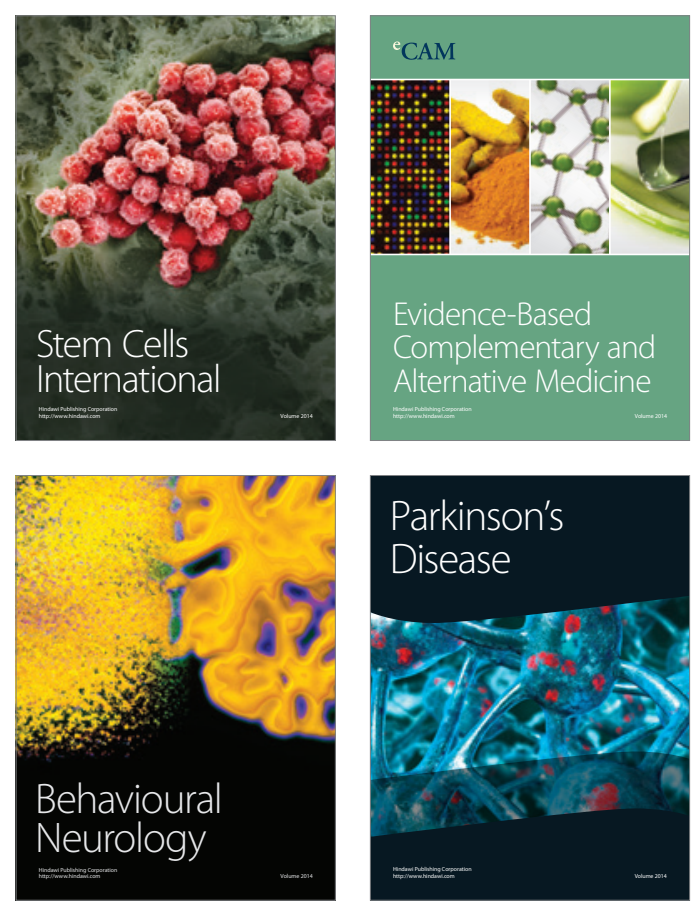

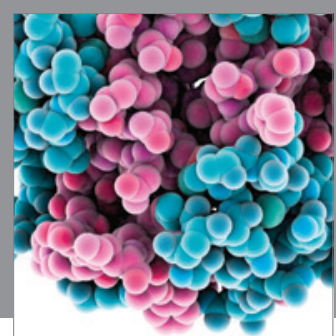

Journal of
Diabetes Research

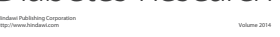

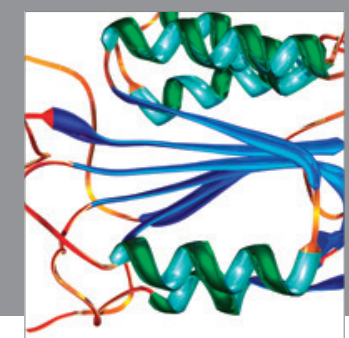

Disease Markers
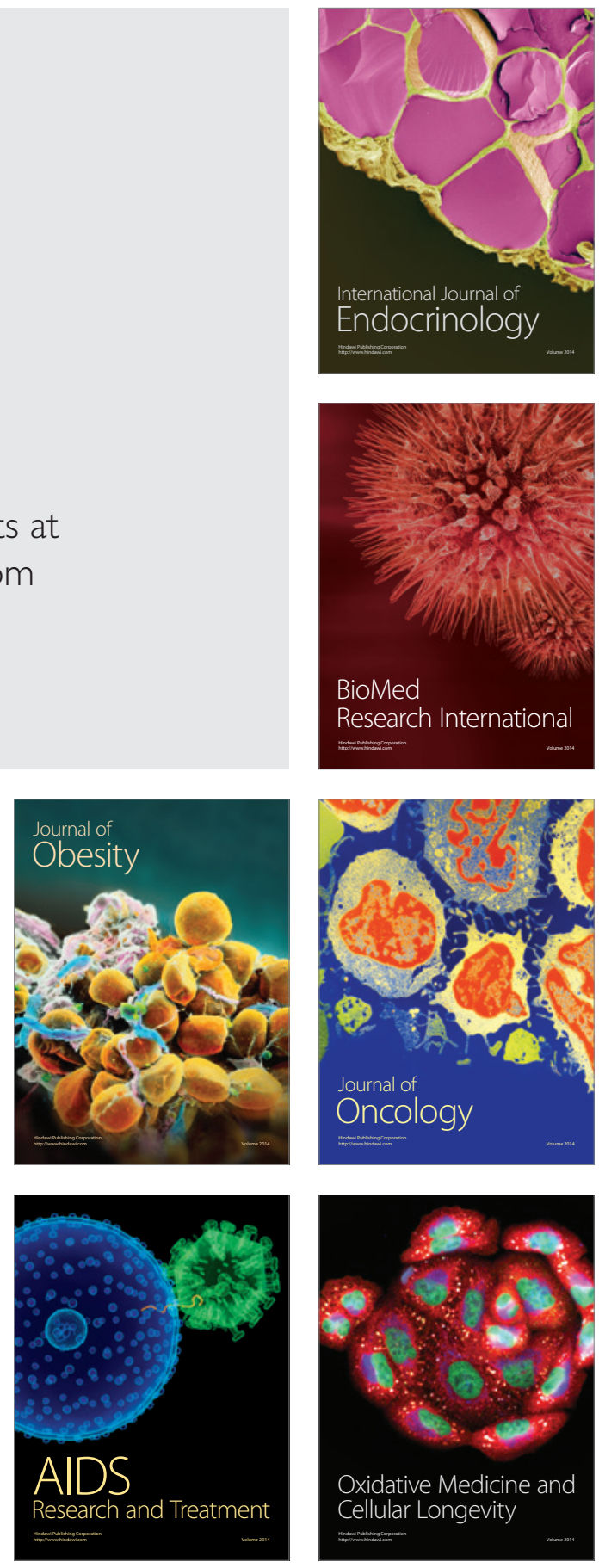